\title{
IAMJ
}

INTERNATIONAL

AYURVEDIC

MEDICAL JOURNAL

\section{EFFICACY OF PANCHAKARMA IN SANDHIVATA W.S.R. TO KNEE ARTHRITIS}

\author{
Tanuja Mehta ${ }^{1}$, Vipin Kumar ${ }^{2}$, Sheetal Verma ${ }^{3}$, Uttam Kumar Sharma ${ }^{4}$ \\ ${ }^{1}$ PG Scholar $1^{\text {st }}$ Year, Department of Panchakarma, \\ ${ }^{2}$ Assistant Professor, Samhita, Sanskrit Evum Siddhanta Dept., \\ ${ }^{3}$ Associate Professor, Samhita, Sanskrit Evum Siddhanta Dept., \\ ${ }^{4}$ Professor and Head, Department of Panchakarma, \\ Uttarakhand Ayurved University, Gurukul Campus, Haridwar, Uttarakhand, India
}

Corresponding Author: tanuja16oct@gmail.com

https://doi.org/10.46607/iamj.3409012021

(Published online: January 2021)

Open Access

(C) International Ayurvedic Medical Journal, India 2021

Article Received: 26/12/2020 - Peer Reviewed: 28/12/2020 - Accepted for Publication: 31/12/2020

Check for updates

\section{ABSTRACT}

Inflammation of knee joint is called knee arthritis. Among various forms of knee arthritis common is degenerative type of knee osteoarthritis It is the major cause of loco motor disability in old age people particularly among women. Analgesics and Non-Steroidal Anti-Inflammatory Drugs (NSAIDs) are the current available pharmaceutical management of knee osteoarthritis which are associated with adverse side effects. Thus, there is need of research in traditional system of medicines for cost effective and long-term management of knee OA. Degenerative Knee osteo arthritis is almost similar to the Sandhivata describes in Ayuveda with respect to aetiology, pathology and clinical features. With the use of medicines Ayurveda also employs the prospective of Panchakarma in the various therapeutic measures, which is a kind of Shodhan Chikitsa. Panchakarma provides various therapeutic benefits as detoxification, improved circulation, spasm and pain relief. Hence objective of this review article is to describe the efficacy of Panchakarma in knee-arthritis with taking consideration of disease mentioned in Ayurvedic classics as Sandhivata

Keywords: Ayurved, Panchakarma, Sandhivata. 


\section{INTRODUCTION}

Arthritis and Knee Joint, Arthritis is the blanket term use to refer more than 100 rheumatic diseases and conditions that affects the joints, tissue surrounding the joints and the other connective tissue ${ }^{1}$. Knee Arthritis includes the primary symptoms of inflammation like Pain, swelling, and stiffness. Knee is the largest synovial joint in humans, which is composed of osseous structures (distal femur, proximal tibia, and patella), cartilage (meniscus and hyaline cartilage), liga- • ments and a synovial membrane. The latter is in charge of the production of the synovial fluid, which provides lubrication and nutrients to the avascular car- tilage ${ }^{2}$. Unfortunately, given the high use and stress $\bullet$ on knee joint, it becomes a frequent site for painful • conditions like $\mathrm{OA}^{3,4}$ which mainly afflicts the knee • joint in the transition period between middle age and $\bullet$ old age. ${ }^{5,6,7}$ particularly in women who are progressing • towards menopause or those who have already set in ${ }^{8}$.

\section{Knee Osteoarthritis-}

Different from inflammatory arthritis, inflammation in $\mathrm{OA}$ is chronic and low-grade inflammation, involving 1. mainly innate immune mechanisms. Synovitis (infil- 2. tration of inflammatory cells into the synovium) is a 3 . common finding of OA and it can be present in early • stages of the disease but is more prevalent towards the more advanced stages and can be related with severity ${ }^{9}$. Previously knee osteoarthritis was interpreted as 1. wear and tear of the articular cartilage disease because 2 . of ageing and not related to inflammation. Although 3. the disease pathophysiology is still poorly understood 4 . and is under investigation, now it is accepted that knee 5 . osteoarthritis is multi factorial in origin where both 6 . inflammatory and biomechanical whole organ disease 7 . processes plays an important role. Knee osteoarthritis 8 . influenced by combination of factors including age, 9 . obesity, joint integrity, genetic predisposition, lower limb alignment, trauma and inflammation by metabolic syndrome. ${ }^{10-17}$ knee osteoarthritis implicit articular cartilage damage, bony osteophytes formation, sclerosis of the subchondral bone and in advanced cases subchondral cyst formation pathologically regardless of the underlying mechanism.

\section{Classification of Knee Osteoarthritis-}

According to its aetiology OA is classified into two groups: primary (idiopathic or non-traumatic) and secondary (usually due to trauma or mechanical misalignment).

One of the clinical classification criteria most frequently used is the one developed by the American College of Rheumatology. ${ }^{18,19}$

Clinical Knee pain for most days of the prior month, in addition to at least 3 of the following:

Crepitus on active joint motion

Morning stiffness less than 30 minutes' duration

Age older than 50 years

Bony enlargement of the knee on examination

Bony tenderness of the knee on examination

No palpable warmth.

Clinical plus radiographic: Knee pain for most days of the prior month, plus radiographic evidence of osteophytes on joint margins in addition to 1 of the following:

Crepitus on active motion

Morning stiffness less than 30 minutes' duration

Age older than 50 years.

Clinical plus laboratory: Knee pain for most days of the prior month, in addition to at least 5 of the following:

Crepitus on active joint motion

Morning stiffness less than 30 minutes' duration

Age older than 50 years

Bony tenderness to palpation

Bony enlargement

No palpable warmth

Erythrocyte sedimentation rate below $40 \mathrm{~mm} / \mathrm{h}$

Rheumatoid factor less than 1:40

Synovial fluid consistent with OA (white blood cell count $<2000 / \mu \mathrm{L})$.

\section{Sandhivata-}

Acharya Charaka was the first person who described the disease separately named "Sandhigata Anila" but has not included under 80 types. According to Ayurveda Pphysiological functions of the body is governed by three Doshas that is, Vata, Pitta, and Kapha. Vitiation of these Doshas leads in disease manifestation. 
As the age progress degeneration of the body parts occurs due to the influence of vata dosha. Sandhivata is the result of such degeneration ${ }^{20}$. Also, Vata get aggravated by various reasons other than ageing like improper diet, injury, exposure to cold, suppression of natural urges etc. vitiated Vata shelter in the joints. Due its Rooksha, it dries up the lubricating synovial fluid inside the joint capsule, degenerates the joints and can causes the early destruction of cartilage. Sandhivata is one of the consequences of this process. Hence Sandhivata is a painful condition of the joint explained in Ayurvedic text under Vatavyadhi 21, 22, 23 which is characterize by following features-

- Shoola (pain)

- Vatapurnadruti Sparsha (sound resembling that made when rub against a balloon or transparent container filled with air)

- Shotha (swelling)

- Vedana during Prasaran and Akunchan (painful movement including extension and flexion)

- Atopa (abnormal sounds due to damage of joints or crepitus)

- Sandhihanti (restriction of joint movements)

\section{Treatment}

Sandhivata is figures as Kashtsadhya Vyadhi due to involvement of Vatadoasha, Madhyam Roga Marga and Dhatu kshaya. Thus, it is important to prevent early degenerative changes along with treating Sandhivata. Ayurveda plays an important role in both of these aspects. A common treatment for Vata Vyadhi has been described by Acharya Vagabhata i.e. repeated use of Snehana (Oleation therapy) and Swedana (Sudation therapy), Basti (Enema) and Mridu Virechana(Mild Purgative) ${ }^{24}$ Acharya Sushruta has mentioned the treatment for Sandhigata Vata clearly i.e. Snehana, Upanaha, Agnikarma, Bandhana and Unmardana ${ }^{25}$.

\section{Efficacy of Panchakarma -}

The therapeutic measures of Ayurveda not only involve use of medicine but also utilizes other approaches such as; Panchakarma ${ }^{26}$. Panchakarma is a very unique therapeutic procedure, because of its preventive, promotive, prophylactic and rejuvenate properties as well as providing a radical cure ${ }^{27}$. Diseases which are associated with pain mainly involve localized symptoms and vitiated Vata dosha. ${ }^{28}$ Panchakarma therapy help to relief localized symptoms in knee osteoarthritis associated with pain such as inflammation, swelling and strain by pacifying the Vata Dosha.

Mode of Action of Various Panchakarma Therapies in Knee osteoarthritis- ${ }^{29}$

\section{Snehana-(Oleation Therapy)}

It is the first line of treatment explained in the classics for Sandhivta as Sneha is antagonist to the degeneration process caused by excessive Ruksha Guna (dry quality) and Khara Guna (rough quality) of vitiated Vata.

1. Abhyanga (Therapeutic/Preventive Herbal Oil Massage)- Abhyanga reduces the provoked Vata, which is responsible for the decay in the Dhatus and for manifestation of features like pain, stiffness, and crackers. According to modern studies, massage stimulates blood circulation and assists the lymphatic system, improving the elimination of waste throughout the body. Absorption through the skin can be enhanced by suspending the drug in an oily vehicle and rubbing it on the skin. ${ }^{30}$

In cases of osteoarthritis, a study found an $88 \%$ improvement when combining Abhyanga with steam and manual traction ${ }^{31}$. Patients reported improvement in joint movement and reduction in joint swelling with oil applications

2. Janu Basti: Janubasti by lubricating or improving the local blood circulation in knee joint, it enhances the mobility of the knee joint and maintains the integrity of the knee joint.

3. Sandhipichu-By nourishing the bone and connective tissue around the knee joint it prevents the degeneration, inflammation in the knee osteoarthritis and heals pain.

4. Sandhi Lepa- It indicated where Kapha Dosha is involved along with Vata and helps to reduce stiffness or effusion in knee osteoarthritis.

Svedana: (fomentation) Svedana is specially indicated in symptoms like Sankocha (contraction or flexion), Ayama (extension), Shula (pain), Stambha (stiffness), Gaurava (heaviness), and Supti (numbness). ${ }^{32}$ 
33 These are the usual clinical manifestations of Sandhigatavata. This panchakarma therapy helps to enables the free circulation in the joints and relaxes the muscles, which further reduces the stiffness and pain, dispenses the symptomatic relief in knee osteoarthritis.

Bashpa Swedan-Ekang Bashpa or Nadi Sweda- when the pain is limited to a part of the body

Pinda Sweda- (bolus formation)-generally done as a local fomentation, applied on the pain afflicted joints.

1. Churna Pinda Sweda- in it wet bolus prepared from analgesic and anti-inflammatory herbal powder used for lubrication in knee osteoarthritis.

2. Patra Panda Sweda (Leaf Bolus Fomentation)fresh leaves of Vata alleviating /pain reliving herbs are used

3. Shashtika Shali Panda Sweda-due to the properties of rejuvenation, nourishment, strengthen the bone and connective tissue it is preferred where there are signs of severe Vata vitiatition and degeneration of knee joints.

Dhara/Seka (Pizhichill) - herbal oil streams over the painful knee joints, Upanaha (Poultice Sudation)- is a type of Svedana indicated in classics ${ }^{34}$ as one of the components in the treatment of Sandhigatavata. ${ }^{35}$ Studies have revealed the fact that lipid medium is highly suitable for penetration of the drug molecule through stratum corneum.

Mriduvirechana- Treatment of Sandhigatavata usually begins with a basic process like Mriduvirechana. It cleanses the body to restore patency of the Srotasa, which improve the access of healing material as well as nourishment to the body components ${ }^{36}$.

Basti-Basti is considered to be best Panchakarma therapy for vitiated Vata and related painful conditions including knee osteoarthritis as it reinforced and rejuvenates the joint and soft tissues, assist fast healing and hence enabled the smooth movements at the knee joints.

Matrabasti- Is a type of Anuvasan Basti ${ }^{37}$ Charaka while assessing the Anuvasana Basti records the digestion of Sneha by the words "Sneham Pachati Pavakah". Basti, through its action on Vata and Agni, promotes the formation of Dhatus. According to
Acharya Charak Matrabasti is always applicable to those emaciated due to overwork, physical exercise, weight lifting, journey on vehicles, in debilitated person as well afflicted with Vata disorders ${ }^{38}$,Matra bas$t i$ is a type of Snehabasti, which is unique therapeutic procedure because of its preventive, promotive, rejuvinative and curative properties and helps to alleviates Vata, nourishes Aasti and Majjadhatu ${ }^{39,40}$ The colon is considered as main seat of Vata, and Vata-alleviating substances administered through the rectocolonic route in Matrabasti are able to have their optimum effect on the seat of Vata ${ }^{41}$.

\section{CONCLUSION}

Although numerous modern treatments for various forms of OA have been identified, they suffer from various drawbacks, such as lack of efficacy, excessive side effects and high cost $\mathrm{t}^{42}$ The current pharmacological management of osteoarthritis includes the administration of analgesics and NSAID's, but their use neither provides adequate pain relief nor deceleration in disease process. In addition, NSAIDs are associated with adverse effects ${ }^{43,44,45}$. Due to which the use of alternative therapies is on the rise. WHO recommends to include traditional system of medicine in global health care ${ }^{46}$ Usually treatment of OA requires treatment of the patient for their entire lifetime; therefore it should be effective, friendly, safe and cheap. The goal of OA treatment for medical profession is not only control symptoms but also prevent disease progression, minimize disability, and improve quality of life. Researchers claimed that Ayurveda treatment outcome is better than or equal to conventional drug for improvement of pain and knee function ${ }^{47}$. Hence it can be concluded that Panchakarma (detoxification technique) has promising relief effect in osteoarthritis. ${ }^{48}$

\section{REFERENCES}

1. Chu, C. R., Millis, M. B., \& Olson, S. A. (2014)/ Osteoarthritis: From Palliation to Prevention: AOA Critical Issues/ The Journal of bone and joint surgery American /volume 96(15), e130/ PMID: 25100783; PMCID: PMC4116563/ doi: 10.2106/JBJS.M.01209.

2. Golovach, I. Yu., Ye. D. Yehudina, \& S.Kh. TerVartanian/ "Management of patients with knee osteoar- 
thritis in accordance with the recommendations of the modern medical societies: focus on ESCEO 2019.

3. "TRAUMA [Online]/ volume 20 no.4 / Aug 2019 / page no. 23-38/ Available at: http://rauma.zaslavsky.com.ua/article/view/178743/18 0470 . Date accessed: 14 Aug. 2020. doi: http://dx.doi.org/10.22141/16081706.4.20.2019.178743.

4. Philippe Richebé, Xavier Capdevila, 3. David Zelman/ The Basics of Osteoarthritis/ WebMD Medical Reference/ June 02, 2020/ Arthritis Foundation, National Institute of Arthritis and Musculoskeletal and Skin Diseases, American Academy of Orthopaedic Surgeons/ Available fromhttps://www.webmd.com/osteoarthritis/guide/osteoarth ritis-basics.

5. Cyril Rivat/ Persistent Postsurgical Pain: Pathophysiology and Preventative Pharmacologic Considerations. Anesthesiology/ ASAPublications/ sep.2018 volume 129(3) /590-607/ doi: https://doi.org/10.1097/ALN.0000000000002238.

6. Akinpelu AO, Alonge TO, Adekanla BA, Odole AC/ A community-based study/ Prevalence and pattern of symptomatic knee osteoarthritis in Nigeria/ Internet Journal of Allied Health Sciences and Practice/ July 2009/Volume 7 Number 3/page no.1.

7. Pal CP, Singh P, Chaturvedi S, Pruthi KK, Vij A./Epidemiology of knee osteoarthritis in India and related factors/ Indian J Orthop/ $2016 \mathrm{Sep} /$ volume 50(5) / 518-522/ PMID: 27746495/ PMCID: PMC5017174/ doi: 10.4103/0019-5413.189608.

8. Davis MA, Ettinger WH, Neuhaus JM, Hauck WW/Sex differences in osteoarthritis of the knee. The role of obesity/ American journal of epidemiology/1988 May/ volume 127(5)/ 1019-30/ PMID: 3358403/ doi:10.1093/oxfordjournals.aje.a114878.

9. Bennett, Coleman and Co. Ltd; c2013/ Osteoarthritis is India's No.1ailment/ Times of India.com [article on Internet] [Updated on 2007 Sep 6, Last accessed on 2011 Jul 31] /Available from: http:/www.articles.timesofindia.indiatimes.com/ 2007-09-06/india/27968801_1_tns-arogya-

osteoarthritis-hiv-and-cancer.

10. Robinson WH, Lepus CM, Wang Q, Raghu H, Mao R, Lindstrom TM, Sokolove J/ Low-grade inflammation as a key mediator of the pathogenesis of osteoarthritis./ Nat Rev Rheumatol/ 2016 Oct/ volume12(10) / 58092./. 2016 Aug 19/ PMID: 27539668/ PMCID: PMC5500215/ doi: 10.1038/nrrheum.2016.136.
11. Chahla J, Piuzzi NS, Mitchell JJ, Dean CS, PascualGarrido C, LaPrade RF, Muschler GF/ Intra-Articular Cellular Therapy for Osteoarthritis and Focal Cartilage Defects of the Knee/ A Systematic Review of the Literature and Study Quality Analysis/ The Journal of bone and joint surgery /American volume, 98(18)/ 1511-1521/ 2016 Sep 21/PMID: 27655978.

12. Arden N, Nevitt MC. Osteoarthritis: Epidemiology. Best Pract Res Clin Rheumatol. 2006 Feb; 20(1):325. DOI: https://doi.org/10.1016/j.berh.2005.09. 007. [PubMed] [Google Scholar].

13. Wluka AE, Lombard CB, Cicuttini FM/ Tackling obesity in knee osteoarthritis/ Nat Rev Rheumatol/ . Epub 2012 Dec 18 / volume 9(4)/ page no.225-35/ doi: 10.1038/nrrheum.2012.224/ PMID: 23247649.

14. Duivenvoorden T, Brouwer RW, van Raaij TM, Verhagen AP, Verhaar JA, Bierma-Zeinstra SM/ Braces and orthoses for treating osteoarthritis of the knee/ The Cochrane database of systematic reviews/2015 Mar 16/ volume 2015(3)/ PMID: 25773267/ PMCID: PMC7173742/ doi: 10.1002/14651858.CD004020.pub3.

15. Riboh JC, Saltzman BM, Yanke AB, Fortier L, Cole $\mathrm{BJ} /$ Effect of leukocyte concentration on the efficacy of platelet-rich plasma in the treatment of knee osteoarthritis/ Am J Sports Med/ 2016 Mar/ volume44(3)/ $792-$

800/ DOI: https://doi.org/10.1177/0363546515580787.

16. Piuzzi NS, Slullitel PA, Bertona A, Oñativia JI, Albergo I, Zanotti G, Buttaro MA, Piccaluga F, Comba FM/ Hip arthroscopy in osteoarthritis: a systematic review of the literature/Hip international: the journal of clinical and experimental research on hip pathology and therapy/ 2016 Jan-Feb/ volume 26(1)/ 8-14/ PMID: 26391259/ doi: 10.5301/hipint.5000299/.

17. Thorlund, J. B., Juhl, C. B., Roos, E. M., \& Lohmander, L. S/ (2015)/ Arthroscopic surgery for degenerative knee: systematic review and meta-analysis of benefits and harms /BMJ (Clinical research ed.)/ 350/ PMID: 26080045; PMCID: PMC4469973 /h2747. https://doi.org/10.1136/bmj.h2747.

18. Zuiderbaan, H. A., van der List, J. P., Kleeblad, L. J., Appelboom, P., Kort, N. P., Pearle, A. D., \& Rademakers, M. V./ Sep-Oct 2016/ Modern Indications, Results, and Global Trends in the Use of Unicompartmental Knee Arthroplasty and High Tibial Osteotomy in the Treatment of Isolated Medial Compartment Osteoarthritis/ American journal of orthopedics (Belle 
Mead, N.J.)/ 45(6), E355-E361/ PMID: 27737301 [PubMed] [Google Scholar].

19. $\mathrm{Wu} \mathrm{CW}$, Morrell MR, Heinze E, et al. Validation of American College of Rheumatology classification criteria for knee osteoarthritis using arthroscopically defined cartilage damage scores. Semin Arthritis Rheum. 2005 Dec; 35(3) :197201. DOI: https://doi.org/10.1016/j.semarthrit.2005.06.002. [PubMed] [Google Scholar].

20. Altman R, Asch E, Bloch D, Bole G, Borenstein D, Brandt K, Christy W, Cooke TD, Greenwald R, Hochberg M, et al./ Development of criteria for the classification and reporting of osteoarthritis. Classification of osteoarthritis of the knee/ Diagnostic and Therapeutic Criteria Committee of the American Rheumatism Association. Arthritis Rheum /1986 Aug/ volume 29(8)/ 1039-49/ doi: 10.1002/art.1780290816./PMID: 3741515.

21. Vagbhatta/Vagbhatta/ Ashtanga Hridayam/ Sutrasthana/ Ayushkamiya Adhyaya/ 1/7./English translation by KRS Murthy/Vol. 1./ Varanasi/ Chaukhambha Sanskrit Samsthan/ 2009/ p. 6.

22. Tripathi Brahmanand Editor Charak Samhita With Hindi Translation, Chaukhamba subhartiprakashan/Varanasi, 2008; 28:618.

23. Kaviraj ambikadutta Shastri, Editor, Sushrutha Samhita, Nidanasthana, Chapter 1, Shloka 28, $11^{\text {th }}$ Edition, Chaukhamba Sanskrit Samsthan; Varanasi: 1997; P. 230.

24. Mahamahopadyaya Sri Vijayarakshita, Srikanthaduttadyam, Madhavanidanam, $22^{\text {nd }}$ chapter, Vatavyadhinidana, Chaukhambasurbharatiprakashan; Varanasi: 2007; P. 520.

25. Daksha Rathod et.al / Effect of Yoga Basti in Sandhivata w.s.r. to Osteoarthritis of Knee Joint/Published online in http://ijam.co.in.

26. Vaidya Yadunandana, Astangahrdaya Of Vagabhata Edited With 'Vidyotini' Hindi Commentary By Kaviraja Gupta, Chaukhambha Prakashan, Varanasi, Reprint 2007, 13th Chapter 1st, 2nd, 3rd Slokas, Page No 96, 97.

27. Vaidya Yadavaji Trikamji Acharya, Susrutha Samhita With Nibandhasangraha Commentary Of Sri Dalhana Acharya, Chaukhambha Surbharati Prakashan, Varanasi, Reprint2012, Chikitsa Sthana, 4th Chapter, 8th Sloka, Page No-820.

28. Dr Ashish Mishra, Dr Pankaj Nigam// Role of Panchakarma in Various Disorders Associated with Pain W.S.R. to Sciatica, Spondylitis and Osteoarthritis / Re- view Article/ Journal of Drug Delivery and Therapeutics/15.07.2018/ Available online on at http://jddtonline

29. Sharma MR, Mehta CS, Shukla DJ, Patel KB, Patel MV, Gupta SN/ Multimodal Ayurvedic management for Sandhigatavata (Osteoarthritis of knee joints)/ AYU [serial online] /2013 [cited 2020 Aug 14]/ volume34/ page no.49-55/ Available from: http://www.ayujournal.org/text.asp?2013/34/1/49 $/ 115447$.

30. Brunton LL editor/ 12th ed./ New Delhi/ McGraw-Hill Professional/ 2011. Goodman and Gilman's The Pharmacological Basis of Therapeutics/ p. 22.

31. Rajorio K, et al./ "Clinical study on Laksha Guggulu, Snehana, Swedana \& Traction in Osteoarthritis (Knee joint)."/ Ayu. /2010. Jan-Mar/ volume 31(1)/ page no. 80-87.

32. Agnivesha, Charaka, Dridhabala. Charaka Samhita Vol. 1, Sutra Sthana Svedadhyaya, 14/24, Shastri K, editor. Varanasi: Chaukhambha Sanskrit Samsthan; 2004. p. 286.

33. Ibidem. Charaka Samhita, Vol. 1, Sutra Sthana, Langhana-Brihaniya Adhyaya, 22/11. :424. [Google Scholar].

34. Sushruta. In: Sushruta Samhita-Vol. 2, Chikitsa Sthana, Svedavacharaniyachikitsa Adhyaya, 32/3. Sharma AR, editor. Varanasi: Chaukhambha Sanskrit Samsthan; 2004. p. 416. [Google Scholar].

35. Ibidem. Shusruta Samhita, Vol. 2, Chikitsa Sthana, Vatavyadhichikitsitam, 4/8. :205. [Google Scholar].

36. Agnivesha, Charaka, Dridhabala . In: Charaka Samhita - Vol. 1, Sutra Sthana Yajjapurushiya Adhyaya, 25/40. Shastri K, editor. Varanasi: Chaukhambha Sanskrit Samsthan; 2004. p. 468. [Google Scholar].

37. Grampurohit, P. L., Rao, N., \& Harti, S. S./ 2014/ Effect of anuvasana basti with ksheerabala taila in sandhigata vata (osteoarthritis)/ Ayu/ volume 35(2)/ pageno.148-151/ available from https://doi.org/10.4103/0974-8520.146225.

38. Satish Kumar Singh N.P.Rai, V.K.Shrivastav/ Role Of An Ayurvedic Compound Drug And Brimhana Basti In The Management Of Sandhivata Viz Osteoarthritis/ Int. J. Res. Ayurveda Pharma/ 2015/ volume(4)/429-434/ Http//Dx.Doi.Org/10.7897/2277-4343.06482.

39. Acharya Y T, Charak Samhita of Agnivesh, Rashtriya Sanskrit Sansthan New Delhi, Chaukambha prakashan Varanasi 2006, P 72.

40. Acharaya Vaidya Jadavjitrikamjieditor Chikitsasthan, Agnivesh, Charak Samhita With Commen- 
tary,Chakarpanidattachaukhambha Sanskrit Sansthanpress, Varanasi.2008: 28: 618.

41. Agnivesha, Charaka, Dridhabala . Charaka Samhita, Sutra Sthana, Snehadhyaya 13/98. In: Tripathi B, Deshpande PJ, editors. Reprint ed. Varanasi: Chaukambha Sanskrit Pratishtan; 2003. p. 284. [Google Scholar].

42. Agnivesha, Charaka, Dridhabala. Charaka Samhita Vol. 2, Siddhi Sthana Snehavyapadasiddhi Adhyaya, 4/53. In: Shastri K, editor. Varanasi: Chaukhambha Sanskrit Samsthan; 2004. p. 1013. [Google Scholar].

43. Ashok Kumar Panda / 2015/ Ayurveda Treatment Outcomes for Osteoarthritis/ J Homeop Ayurv Med /4:e115/ doi: 10.4172/2167-1206.1000e115.

44. Bennett, Coleman and Co. Ltd; c2013/ Osteoarthritis is India's No.1 ailment/ Times of India.com [article on Internet] [Updated on 2007 Sep 6, Last accessed on 2011
Jul
31]
/Available

from: http://www.articles.timesofindia.indiatimes.com/ 2007-09-06/india/27968801_1_tns-arogya-

osteoarthritis-hiv-and-cancer.

45. 44.Eustice C/ Guide to Osteoarthritis, Part 4 of 5Osteoarthritis Medications and Other Drug Options/ About.com [article on Internet] /c2013/ [Updated on 2007 Apr 7, Last accessed on 2011 Aug 5] /Available from: http://www.arthritis.about.com/od/oa/a/Osteo_art hritis_4.htm.

46. NSAID use associated with future stroke in healthy population/ [article on Internet]/ Sweden/ The heart.org by WebMD/ c1999-2012/ [Updated on 2010 Sept8, Last accessed on 2011 Aug 26] /Available from: http://www.theheart.org/article/1119849.

47. World Health Organization/ Benchmarks for Training in Traditional/Complementary and Alternative Medicine: Benchmarks for Training in Traditional Chinese Medicine/Vol. 30/ Geneva/2010.

48. Sunil Jawla, Gupta AK, Rachit Singla, Varun Gupta/ (2009)/ General awareness and relative popularity of allopathic, ayurvedic and homeopathic systems/Journal of Chemical and Pharmaceutical Research /volime1/pageno. 105-112/available from-: http://jocpr.com/.../JOCPR-10.pdf.

49. Chopra A, Saluja M, Tillu G, Sarmukkaddam S, Venugopalan A, Narsimulu G, Handa R, Sumantran V, Raut A, Bichile L, Joshi K, Patwardhan B/ Ayurvedic medicine offers a good alternative to glucosamine and celecoxib in the treatment of symptomatic knee osteoarthritis/ a randomized, double-blind, controlled equivalence drug trial/ Rheumatology (Oxford, Eng- land/2013 Aug/ volume 52(8)/ 1408-17/ PMID:

23365148./ doi: 10.1093/rheumatology/kes414.

\section{Source of Support: Nil \\ Conflict of Interest: None Declared}

How to cite this URL: Tanuja Mehta et al: Efficacy Of Panchakarma In Sandhivata W.S.R. To Knee Arthritis. International Ayurvedic Medical Journal \{online\} 2021 \{cited January, 2021\} Available from: http://www.iamj.in/posts/images/upload/212_218.pdf 